\title{
Computer Simulation of Thermal Modeling of Primary Lithium Cells
}

\author{
Young 1. Cho', Harvey Frank ${ }^{2}$ and Gerald Halpert ${ }^{2}$ \\ Drexel University (1) and Jet Propulsion Laboratory (2)
}

\section{ABSTRACI}

The objective was to gain a better understanding of the safety problem of primary $\mathrm{LI}_{-} \mathrm{SOCl}_{2}$ and $\mathrm{LI}-\mathrm{SO}_{2}$ cells by carrying out detall thermal modeling work. In particular, the transient heat generation rates during moderate and extremely high discharge rate tests of $\mathrm{Li}_{-} \mathrm{SOCl}_{2}$ cells were predicted and compared with those from the electrochemical heating. The difference between the two may attributed to the lithlum corrosion and other chemical reactions. The present program was also tested for charging tests of $\mathrm{LI}_{1} \mathrm{SO}_{2}$. In addition, the present methodology should be applicable to other primary cylindrical colls as well as rechargeable battery analyses with minor modifications.

\section{IIIRODUCTION}

The present investigation is an extension of our earlier work of a simple transient model, which used the lumped-heat-capacity method to predict the time-dependent cell temperature of primary lithlum-thionyl chloride ( $\mathrm{LI}-\mathrm{SOCl}_{2}$ ) cells [1]. However, the thermal impact of internal thermal resistances on the overall heat dissipation was not included in the previous analysis. In addition, the heat transfer coefficient $h$, which is a function of temperature and position, was assumed to be constant in the previous study to demonstrate the validity of methodology.

The purpose of the present thermal modeling work was to develop a computer program to take into account the effects of internal thermal

$$
19-20
$$

PRDEEDING PAGE BLANK NOT NEMAND 
resistances, non-linear heat transfer coefficient, and radiation. In so doing, we wanted to identify the mechanism of heat dissipation in typical cylindrical Iithium cells. In addition, we wanted to calculate the net amount of heat generated from the cell during the discharging or charging procedure, from which the safety problem of $\mathrm{LI}_{-} \mathrm{SOCl}_{2}$ and $\mathrm{LI}_{-} \mathrm{SO}_{2}$ (lithium-sulfur dioxide) battery systems could be better understood.

Frank et al. pointed out in their study of safety hazards associated with the charging of $\mathrm{LI}_{-} \mathrm{SO}_{2}$ cells [2] that the cell safety depended on a number of variables such as cell type, charging current, temperature and cell condition prior to charging (discharge history), etc. Results of the charging tests were reduced to the form of a curve called "safety envelope", that related time to explosion with charging current. The time required to reach a dangerous condition increased as the charging current was reduced. Hence, one of the objectives of the present investigation was to calculate the threshold time, which will allow the rellable prediction of the dangerous region for a system without first conducting extensive experimental measurements.

The available experimental data for $\mathrm{Li}_{-} \mathrm{SO}_{2}$ cells were in the form of instantaneous cell wall temperature and operating cell voltage at a given charge current. All charging tests were carrled out with power supplies, which were adjusted to provide a constant current, thus allowing voltages to float. During the charging tests the cells were placed in temperature-controlled chambers at a given temperature so that the ambient temperature was remained constant during the tests.

\section{DESCRIPTION OF THE PROGRAM}

Two computer programs were developed for the present thermal modeling work. The program A calculates instantaneous heat generation rates using the cell wall temperature as experimental input during discharging or charging test, while the program $B$ calculates instantaneous cell wall temperature with heat generation rates if avallable from calorimetric measurements. In both cases the internal temperature distribution within the cell would be automatically produced. Also, electrolyte consumption schedules could be given as input such that a dry or flooded cell could be simulated. It was pointed out that the correct estimation of electrolyte during discharging or charging 
test was important in the calculation of thermal mass of a cell, since electrolyte usually accounts more than fifty percent of the total thermal mass in a fully discharged condition.

Note that the programs were written in the Basic Language and can be run on the IBM PC XT or AT. Both programs are fully self-contained and the only input data required are either the transient cell wall temperature for program $A$ or heat generation rate obtained from the calorimetric measurement for program B.

These computer programs were developed as a tool, with which one can carry out a computer experiment to identify several important safety problems such as the effects of the ambient temperature, time required to reach a dangerous condition, discharge or charge current, and amount of electrolyte, etc. To do this, one needs to have a set of data of both instanteneous cell wall temperature and heat generation rate obtained from the calorimetric measurement during discharging or charging test for a particular type of a cell. Once we establish the base line test conditions for the computer simulation by cross-checking the predicted temperature with experimental data, one can conduct a series of parametric studies by changing a parameter at a time such as amblent temperature, charging current, amount of electrolvte, etc.

In the following section, the thermal modeling work will be described in detall, which should help us to understand the full capability and limitation of the computer simulation based on the present thermal model.

\section{DESCRIPTION OF IHE IHERMAL MODELIMG}

From the heat transfer point of view, the total amount of heat generated from the cell can be expressed by the sum of the sensible heat stored within the cell and the heat dissipated out of the cell via convection and radiation mode. Although the heat transfer coefficient by a forced convection can be larger than that by a natural convection by an order of magnitude, the former was not considered here from the fact that the forced convection cooling requires power from the primary battery system, thus diluting the available power density. Hence, the convection in the present thermal modeling work 
consists of the natural convection only.

When the cell wall temperature is near the ambient temperature, the heat dissipation by radiation is considered relatively small. However, with increasing cell temperature, the amount of heat to be dissipated out by radiation could be significant. This is true when a cell temperature is in the range of 80 to $120^{\circ} \mathrm{C}$, as lllustrated in Fig. I which was for a $\mathrm{D}-\mathrm{size} \mathrm{LI}-\mathrm{SOCl}_{2}$ cell with heat generation rate of $10 \mathrm{~W}$. The solid points in Fig. 1 represent the heat dissipation by convection only, while the open points include heat dissipation by radiation. As demonstrated, if radiation is not included in the heat dissipation analysis, the predicted temperature is well above the actual level by almost 100 percent even in the range of 80 to $120^{\circ} \mathrm{C}$. Thus, the radiation mode of heat dissipation is kept in the present thermal modeling. In summary, the total amount of heat generated from the cell during discharging or charging test can be written as

$$
Q_{\text {TOTAL }}=Q_{C V}+Q_{R}+Q_{S 1}+Q_{S 2}
$$

where

$$
\begin{aligned}
& Q_{C V}=\text { heat dissipation to the surroundings by convection } \\
& Q_{R}=\text { heat dissipation to the surroundings by radiation } \\
& Q_{S 1}=\text { sensible heat (energy stored within the cell) } \\
& Q_{S 2}=\text { sensible heat correction due to the internal temperature } \\
& \text { variation by heat conduction. }
\end{aligned}
$$

The heat balance equation can be rewritten in terms of the actual parameters:

$Q_{\text {TOTAL }}=h A\left(T_{w}-T_{a}\right)+F_{1-2} \in \sigma A\left(T_{w}{ }^{4}-T_{a}^{4}\right]+C_{p} M \frac{d T}{d t}+Q_{S 2}$

where $T_{w}$ and $T_{a}$ are the cell wall temperature and ambient temperature, respectively. Since $Q_{S 2}$ includes the thermal resistance network introduced by Cho (1.e., Flgure 8,[3]) and associated heat conduction analysis, the last term could not be expressed explicitly here. 


\section{HEAT CONYECTION}

The first term in Eq. (2) represents the amount of heat removed from the cell surface to the environment via natural convection. In the cylindrical shape cell, there are three different areas, which are the side, top and bottom surfaces. The heat transfer coefficient from each surface is quite different and is a non-linear function of the wall temperature, which again varies with time. Note that the natural convection phenomena from the side, top and bottom walls of the cylindrical shape cell are well established. Hence, using the available experimental data, the dimensionless heat transfer on each wall surface was calculated as a function of the Prandtl and Rayleigh numbers, leading to the calculation of the Nusselt number. The mathematical expressions of the Nusselt numbers in the side, bottom and top surfaces were given in Cho [3]. In addition, the PrandtI number, thermal conductivity of air and the values of $g \beta / v^{2}$ necessary for the calculation of the Rayleigh number were given as a function of temperature in Cho [3]. This was converted into the corresponding heat transfer coefficient using a characteristic length such as the cell height or diameter. Using the local heat transfer coefficient, the amount of heat convected out from each wall surface was calculated and summed together to produce the total heat convected to the surroundings.

In so doing, the bottom wall surface posed some uncertainty because the cell could be placed on top of a plastic, wood, or metal shelf during the discharge or charge tests, thus preventing natural convection from occurring from the bottom wall. Depending on the shelf materlal and the contact resistance between the cell bottom surface and shelf, the conduction heat transfer from bottom surface to shelf could vary significantly. However, the effect of the shelf was not considered in the present thermal modeling, and heat was assumed to be removed from the bottom wall by the natural convection mode alone. Of note is that from the calculation of the present thermal modeling the heat dissipation from the bottom wall by convection was found to be relatively small compared with those from the side one.

When one has a fairly large size heat sink under the bottom wall, the effect of the heat sink can be significant and should be carefully examined. However, in many aerospace applications, such addition of heat sink is 
considered not beneficial due to the associated weight gain, which is directly related to the launch cost. Also note that for a multi-cell arrangement as found in most practical applications of these lithlum cells, the active surface area available for heat convection (and radiation) is lesser per cell than a single cell condition. Thus, the heat convection calculation based on the actual cell arrangement should be carried out to estimate the correct amount of heat dissipated out by comvection. The multi-cell analysis should constitute future work.

\section{HEAT RADIATION}

The second term, radiation heat, represents the energy dissipated out by the radiation mode. The amount of radiated energy is proportional to the fourth power of the surface temperature (in the absolute temperature scale), in Eq. (2). Hence, with increasing cell temperature, the role of radiated energy becomes quite important. In general, the amount of heat transferred by radiation depends on the following parameters;

$$
\begin{aligned}
F_{1-2}= & \text { configuration factor from wall to the surroundings } \\
& \text { (geometric constant) } \\
= & \text { emmisivity ( surface property) } \\
A \quad= & \text { active area for radiation } \\
T_{W}, T_{a}= & \text { cell surface temperature and ambient temperature, respectively. }
\end{aligned}
$$

The values of the configuration factor and the emmisivity of the lithium cells used in the present analysis were unity and 0.8 , respectively, simulating a single cell test condition. The total surface area of the cell was used as the active radiation area in the present analysis. However, the radiation from the bottom wall should not be included in the analysis when the cell is placed on a shelf. Note that for a multi-cell test one has to calculate the configuration factor using the actual multi-cell arrangement, which could be substantially smaller than unity. 


\section{SENSIBLE HEAT}

The sensible energy means the energy stored within the cell due to a temperature rise of a cell during discharge or charge process. The third term in Eq. (3) represents the product of the total thermal mass and wall temperature rise during $\Delta t$, assuming that the cell internal temperature is the same as the wall temperature.

However, cell internal temperatures vary from cell wall temperature at any given time $t$ during discharging or charging process, which was caused by the outward heat conduction. Hence, the sensible heat must be corrected to take into account the effects of internal temperature variation within the cell. To determine the local temperature in each cell component at timet, the thermal resistance of each cell component (such as cathode, anode, separator, electrolyte, and case can) was calculated in a similar manner introduced by Cho [3]. Accordingly, the sensible heat correction was obtained using the local temperature rise of each cell component. Of note is that the present program has the cell specifications of geometry and component materials for cylindrical $0-s i z e \mathrm{LI}-\mathrm{SOCl}_{2}$ and $\mathrm{Li}_{-} \mathrm{SO}_{2}$ (i.e., Navy's sonobuoy cell) cells. Thus, the only geometric input required for the calculation of the thermal resistance of cell components is to specify $D$ for the $D$ size cell or $N$ for the $\mathrm{LI}_{-} \mathrm{SO}_{2}$ cell.

In addition, the amount of liquid electrolyte varles with the depth of discharge. Since the thermal mass, defined as the product of mass and specific heat, of electrolyte, is about one third or half of the total thermal mass of the primary lithium cells, it is very important to provide a correct information on the actual amount of electrolyte as a function of time. For example, the electrolyte limited cell will have almost no liquid electrolyte near the end of discharge. Thus, substantially less thermal energy can be stored within the cell near the end of discharge. Hence, the thermal modeling presented here was developed to take into account the effect of actual electrolyte consumption as a function of discharge.

Intuitively, the flooded cell should provide more thermal mass during discharge process, thus being safer from the heat management point of view than the electrolyte limited cell. The present thermal model can be used to find how much better the flooded cell would be compared with the electrolyte limited cell, or what amount of the excessive electrolyte is needed to avold or 
delay the unsafe condition for a given type of a cell. Thus, the initial amount of electrolyte and the consumption rate could be given as a part of input data, if desired.

\section{RESUILIS AMD DISCUSSION}

Looking at the discharge mechanism of the lithium primary cells, the total amount of heat generated from the cell during discharge is the sum of that from the electrochemical reaction and chemical reactions. In general, the amount of the heat from the electrochemical reaction is given by the product of the polarization voltage and discharge current, while that of chemical reaction is not established well.

During the charging procedure, the amount of total input energy can be expressed by the product of the charging current and the operating cell voltage. Similarly, the excessive input energy applied during the charging test may be given by the product of the charging current and the voltage difference between the open-circuit- voltage (OCV) and operating voltage. However, it is not known what percentage of the excessive input energy would be converted into heat. The present thermal modeling work was partly initiated in an attempt to answer this question.

\section{Lit-SOCl 2 celle}

\section{a) Moderate Discharge Rate Test}

A D-size cell was discharged under a constant load of 0.5 ohms. The cell wall temperature and operating cell voltage were recorded as a function of time and shown in Fig. 2. The cell wall temperature was gradually increased from the ambient condition of $22^{\circ} \mathrm{C}$ to an asymptotic value of $85^{\circ} \mathrm{C}$, while the cell voltage dropped from the maximum value of $3 v$ at $t=60 \mathrm{~min}$ to $1.19 \mathrm{~V}$ near the end of test (1.e., at $t=282 \mathrm{~min})$. The transient cell wall temperature was used as the input for the present program and the corresponding heat generation rate was calculated accordingly.

Figure 3 shows the predicted heat generation rate from the present model together with the electrochemical heatings based on the thermoneutral potential 
$\left(E_{H}\right)$ of $3.72 \mathrm{~V}$ ( see the dashed line in Fig. 3). The predicted heat rates are in good agreement with those calculated with the thermoneutral potential in the range of $t=0$ to $120 \mathrm{~min}$. After $\mathrm{t}=120 \mathrm{~min}$ when the cell operating cell voltage began to show substantial drop, the actual predicted heat rate was consistently smaller than those of electrochemical heating, indicating that the electrochemical heating based on the polarization during this period (i.e., approaching the end of discharge) is not a good measure of the total heat produced in the cell.

Figure 4 shows the contributions of energy used in the form of convection, radiation, sensible energy, and sensible energy correction due to heat conduction. As shown in the flgure, the sensible energy was a dominant mode of the energy use in the beginning of discharge, whlle near the end of test convection and radiation accounted almost all the heat produced within the cell. in addition, the sensible heat correction due to heat conduction was negligible throughout the entire discharge period.

\section{b) Extremely High Discharge Rate Test}

To test the present program, an extremely high discharge rate test was chosen. The mechanism of heat dissipation from the cell was examined for this extreme case. Experimental data were taken from Dey [4] and shown in Fig. 5, which was obtained by external short circuit using a typical jellyroll type D-size $\mathrm{LI}-\mathrm{SOCl}_{2}$ cell. Of note is that the cell was exploded at $\mathrm{t}=9.6 \mathrm{~min}$.

The predicted core temperature together with the experimental wall temperature was presented in Fig. 6. Prior to the explosion, the temperature difference between wall and core was found to be $28^{\circ} \mathrm{C}$. The core temperature almost reached the melting point of lithium $\left(1 . \theta_{1}, 179^{\circ} \mathrm{C}\right)$ while the wall temperature was well below that.

Figure 7 shows the predicted heat generation rate ( $s \theta \theta$ the solid line) and the electrochemical heatings based on $E_{H}$ (see the dashed line). Of note is that the curves of electrochemical heating was shifted to the right by $0.5 \mathrm{~min}$ to match the initial slopes with the predicted one. The predicted heat rate gave a good agreement with the calculated one with $E_{H}$, confirming the validity of the present program. 
To understand the mechanism of heat dissipation during the extremely high discharge rate test, the contributions of convection, radiation, sensible heat and sensible heat correction due to heat conduction are shown in Fig. 8 . In the beginning of discharge, the sensible accounted almost all the heat produced within the cell. However, approaching the explosion, the contribution of the sensible heat, $Q_{S 1}$, decreased gradually while the amount of heat due to convection, radiation and conduction increased. It is interesting to note that the sum of convection and radiation only accounted about 40 percent, while the conduction took the largest portion of the total heat, approximately 35 percent. This clearly indicates that one must include the sensible heat correction due to heat conduction in the thermal modeling of high discharge rate tests of lithlum cells.

\section{$\mathrm{H}_{-\mathrm{SO}} \mathrm{Cells}$}

The present program was tested for charging tests of $\mathrm{LI}-\mathrm{SO}_{2}$ cells. Some of the results will be briefly described. The predicted instantaneous heat generation rate obtained from the Navy's $\mathrm{LI}_{-} \mathrm{SO}_{2}$ cells (identified as cell:4 for the State-Of-Charge effect test at JPL) was found to be smaller than the excessive amount of input energy calculated using $O C V$. Note that the excessive input energy was defined as the product of the current and the difference between the cell operating voltage and $O C V, I\left(E_{0}-O C V\right)$. However, approaching a large explosion point, the present model predicted a significant increase in the heat generation rate, suggesting that a vigorous chemical reaction might have started during this period.

Considering the fact that during discharging tests the predicted heat rate was almost equal to or larger than the electrochemical heating, the results obtained from the simulation of charging tests showed the opposite trend. The excessive input energy was substantially larger than the predicted heat rate, indicating that a good part of input energy was consumed for some unknown chemical reactions during charging tests.

The break-down of the heat generation rate into convection, radiation, sensible heat, and sensible heat correction due to conduction was also examined. In the beginning and ending periods of the charging test, the 
sensible heat was large, absorbing the significant percentage of the total heat generated from the cell. However, in the middle period of the test, the sensible heat was found to be very small due to the fact that the cell temperature remained almost unchanged during this period. In contrast, the heat dissipated out by convection and radiation were found to increase consistantly with time.

\section{SUMmARY AMR COMCLUSIOMS}

Two programs were developed as a tool to investigate the thermal performance of primary lithium cells. Program A predicts the instantaneous heat generation rate while Program $B$ calculates the instantaneous wall temperature. In both cases, internal temperature distributions were automatically produced, and the contributions of heat convection, radiation, internal energy stored within the cell (1.e., sensible heat) and its correction due to heat conduction were also identified. These results were used to understand the mechanis $m$ of heat dissipation from the lithium cells during discharging or charging tests.

internal thermal resistance of each cell component was calculated based on the actual design parameters, built-in in the present program. In addition, electrolyte consumption schedules could be given as input such that a dry or flooded coll could be stmulated. The major findings will be briefly highlighted below:

1. During discharging test runs, the predicted heat rate gave a good agreement with those obtained with the electrochemical heating based on thermoneutral potential, I(EH$\left.-E_{0}\right)$.

2. Under normal discharge rate conditions, convection and radiation were dominant heat dissipation modes.

3. However, approaching the explosion or for extremely high discharge rate cases such as external short circuits, convection and radiation accounted only 
forty percent of the total heat produced.

4. During the most period of the charging test, the predicted heat generation rate was found to be consistently smaller than the excessive input energy given by $1\left(E_{0}-O C V\right)$. However, approaching the explosion point, the predicted heat rate showed a significant increase, suggesting a vigorous chemical reaction occurring within the cell.

5. Time-history of convection, radiation, sensible heat, and conduction was calculated from the thermal modeling analysis both $\mathrm{LI}_{-} \mathrm{SOCl}_{2}$ and $\mathrm{Li}_{-} \mathrm{SO}_{2} \mathrm{Cell}$, which helps us to better understand the overall thermal behavior of the cell during discharging charging tests.

A series of parametric investigations using the present thermal modeling program might help us to identify the unsafe operating condition of the primary ilthium cells. Of note is that the present program is applicable to other primary cylindrical cells with minor modifications. In addition, the present methodology should be valid for prismatic or button type lithium cells as well as for rechargeable battery analyses, in general.

\section{ACKMOMULEOEEEMII}

The first author acknowledges the support from the Jet Propulsion Laboratory, California Institute of Technology. 


\section{MOMEMCLATURE}

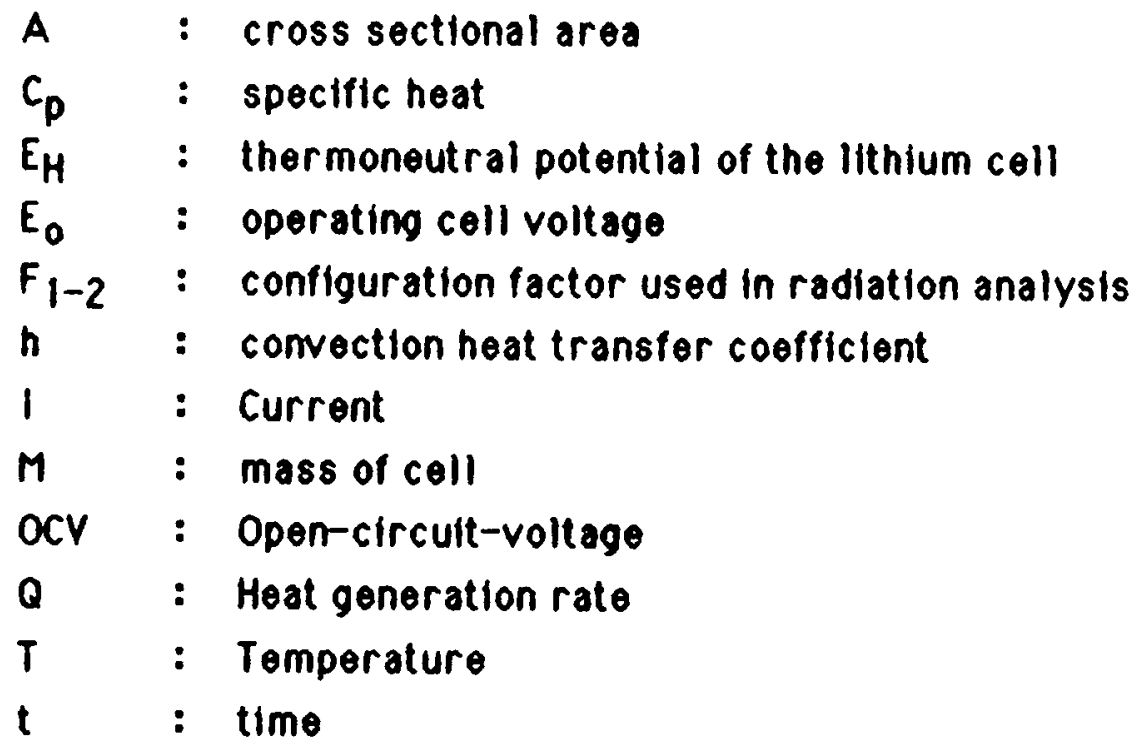

Groeks

: $\quad$ emmisivity
: Stefan-boltzman constant

Subscriptions

a. : ambient

w: coll wall

\section{REFEREMCES}

1 Y.I. Cho and G. Halpert, Heat Dissipation of High Rate LI-SOCl 2 Primary Cells, J. of Power Sources, 18, (1986), pp. 109-115. Also, presented at the 1985 Goddard Space Fllght Center Battery Workshop, Nov.19-21, 1985, Greenbelt, MD.

2. H. Frank, G. Halpert, D.D. Lawson, J.A. Barnes and R.F. Bis, Safety Hazards Assoclated with the Charging of Lithim /Sulfur Dioxide Cells, J. Power Sources, 18, (1986), pp.89-99.

3. Y.l. Cho, Thermal Modeling of High Rate Li-SOCl 2 Primary Cylindrical Cells, to be published in the J. Electrochemical Society.

4. A. N. Dey, Sealed Primary Lithium-Inorganic Electrolyte Cell, Final Report ERADCOM-TR-74-0109 F, July (1978). 


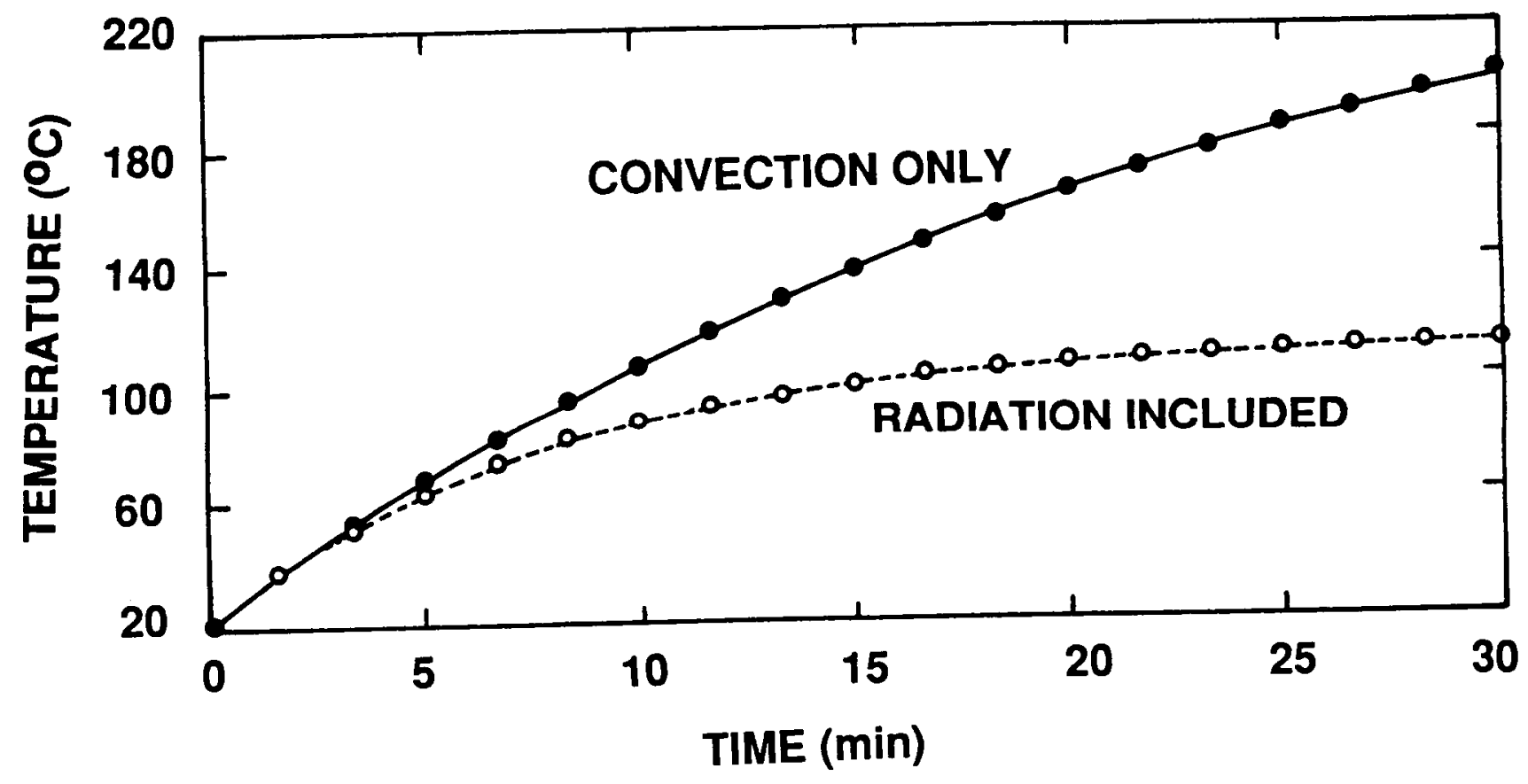

Figure 1. Predicted temperatures for a $\mathrm{D}$-size $\mathrm{Li}_{-} \mathrm{SOCl}_{2}$ cell with heat generation rate of $10 \mathrm{~W}$. 

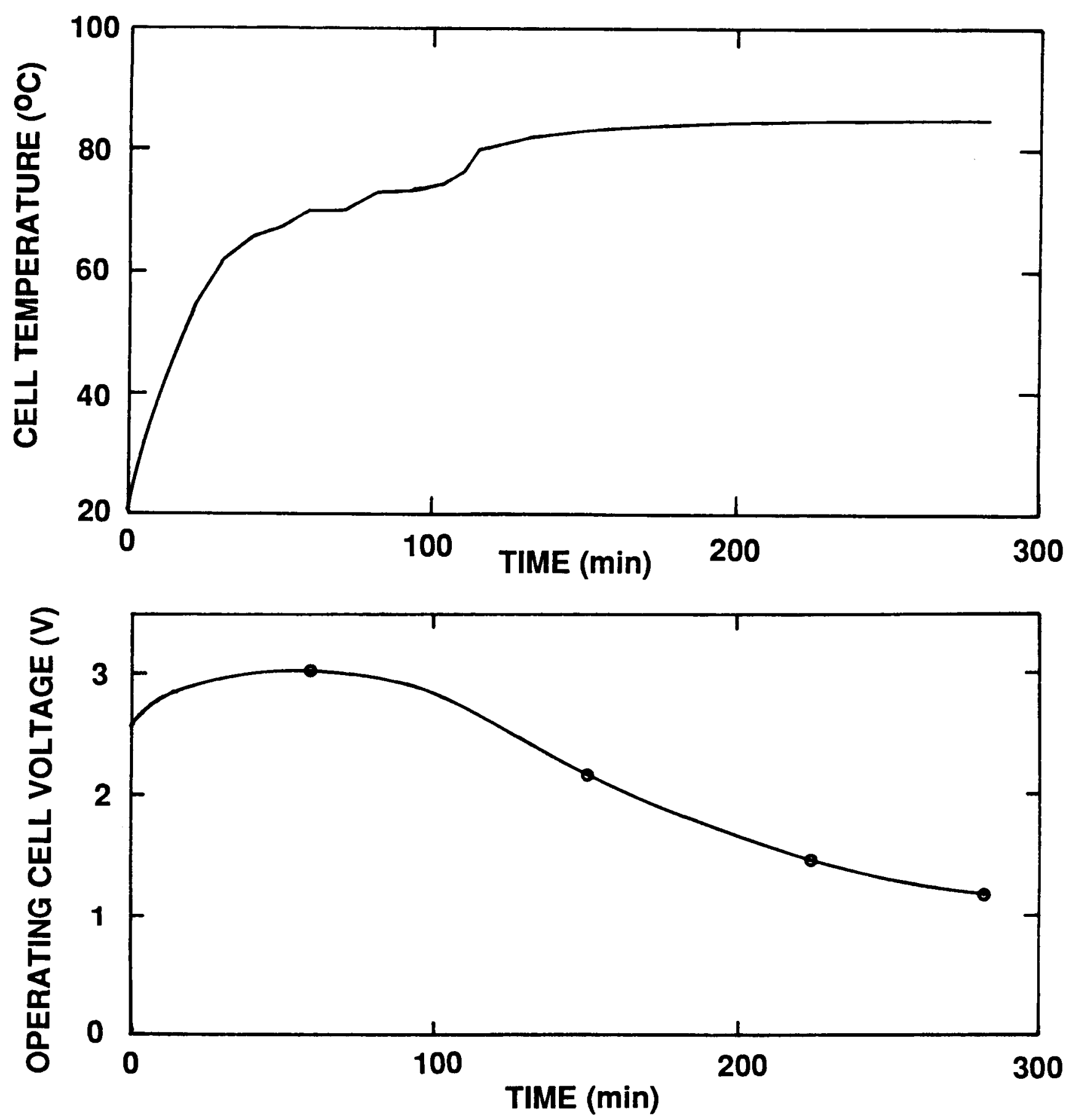

Figure 2. Experimentally measured cell wall temperature and operating cell voltage vs. time during the discharge test under a constant load. 


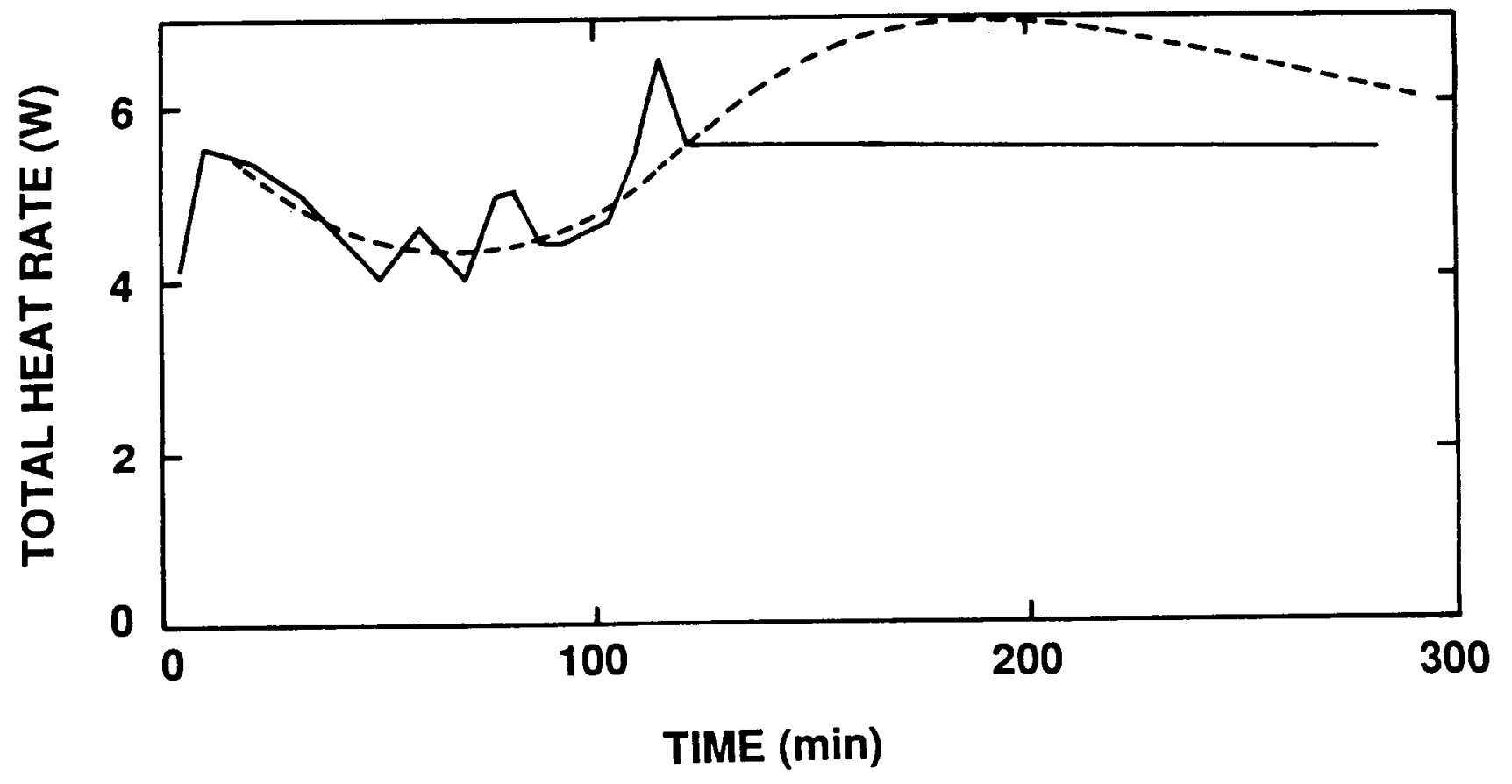

Figure 3. Prediction of the total heat rates from the present model (solid line) and the calculated results based on the thermoneutral potential of $3.72 \mathrm{~V}$ (dashed line) for the discharge test under constant load. 


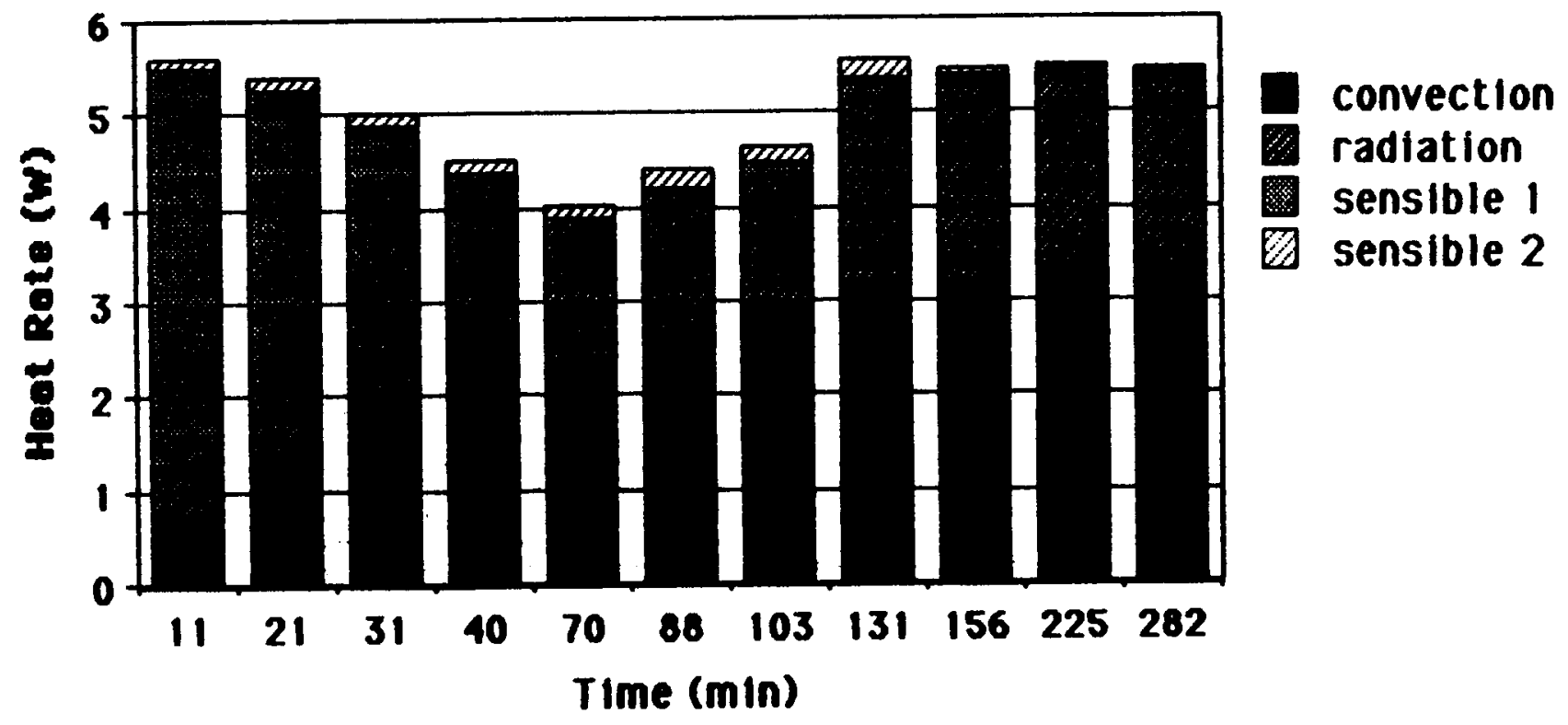

Figure 4. Contributions of convection, radiation, sensible energy (1) and sensible energy correction due to conduction (2) for the discharge test under constant load. 


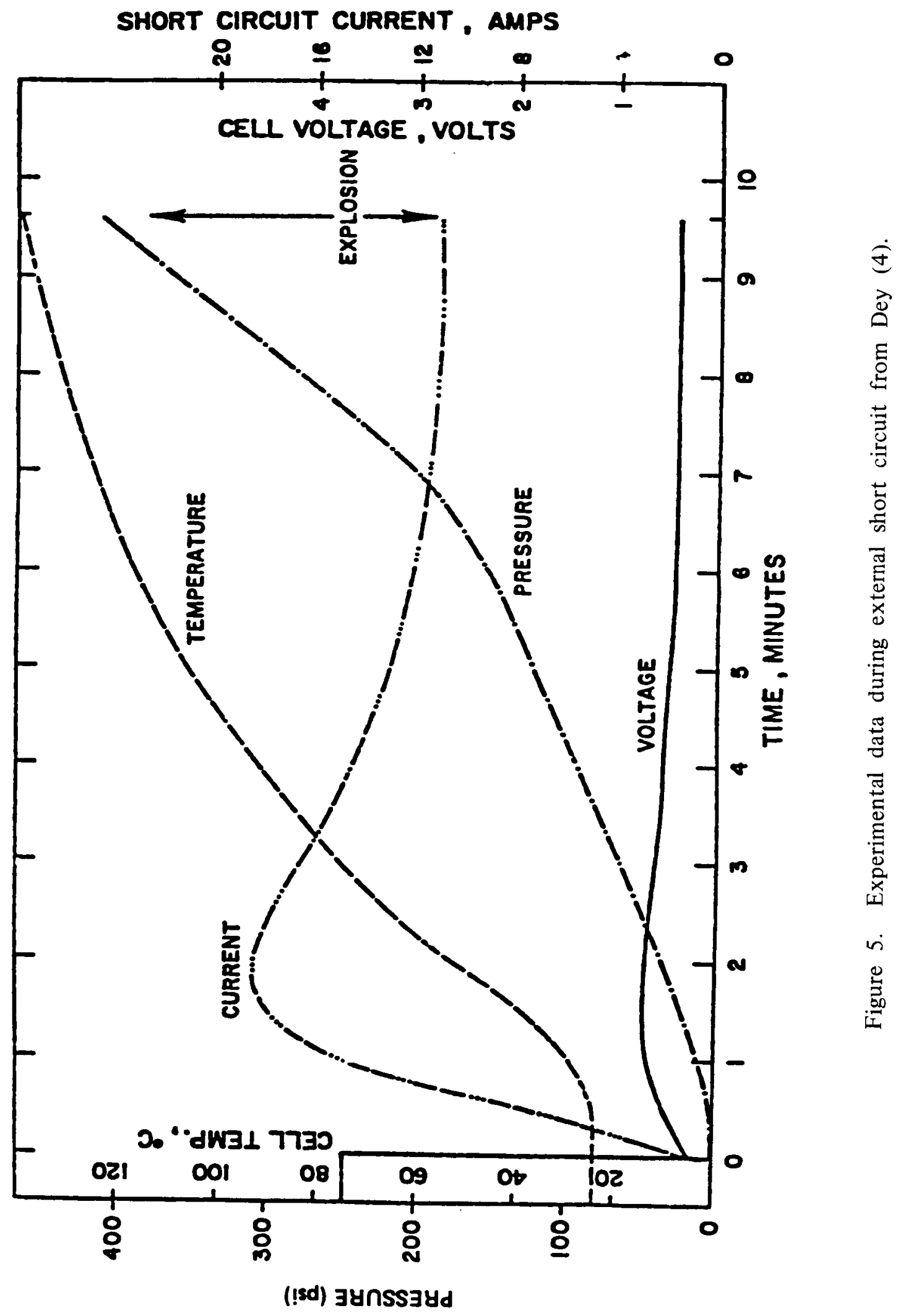




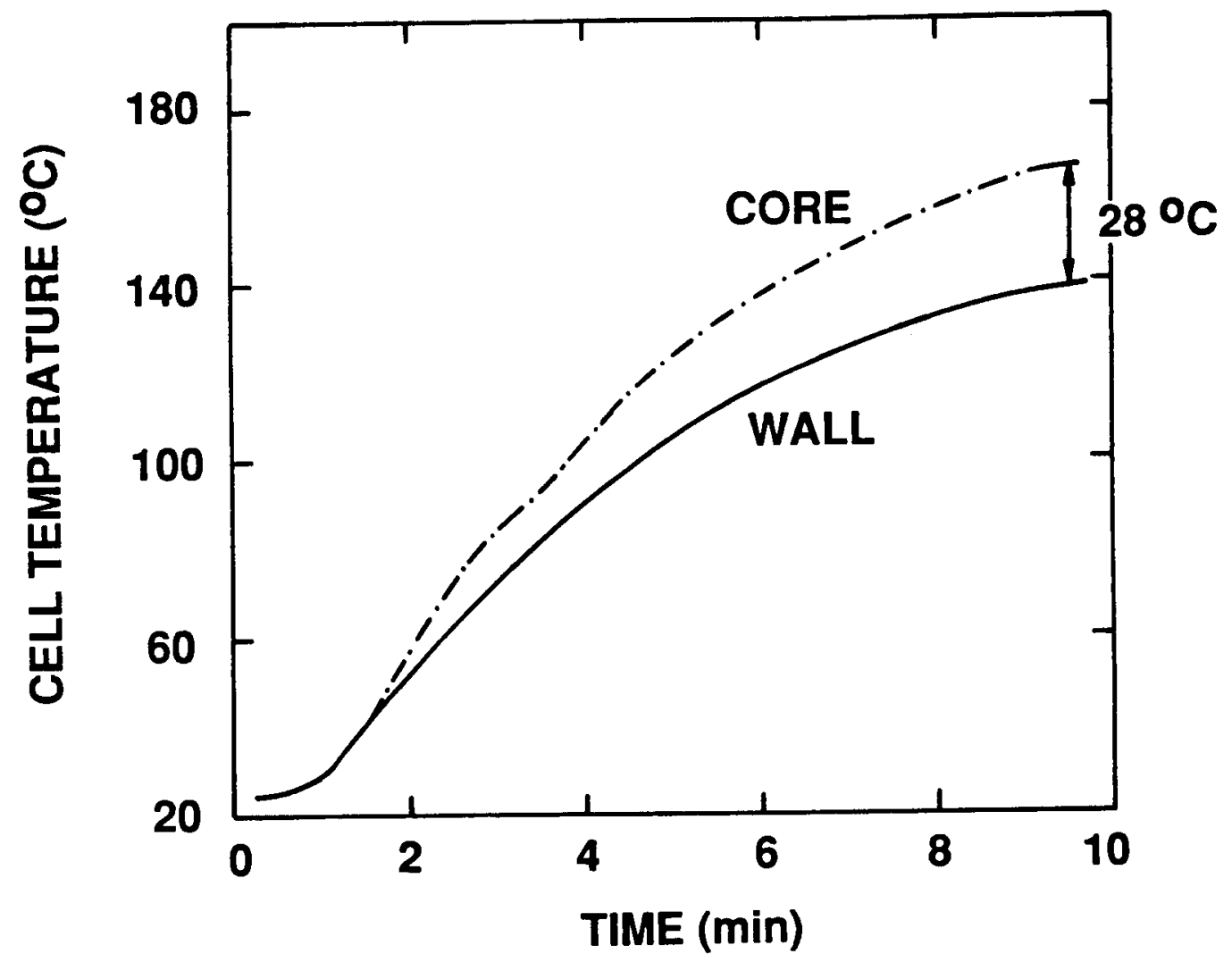

Figure 6. Prediction of core and wall temperatures from the present model for the short circuit test. 


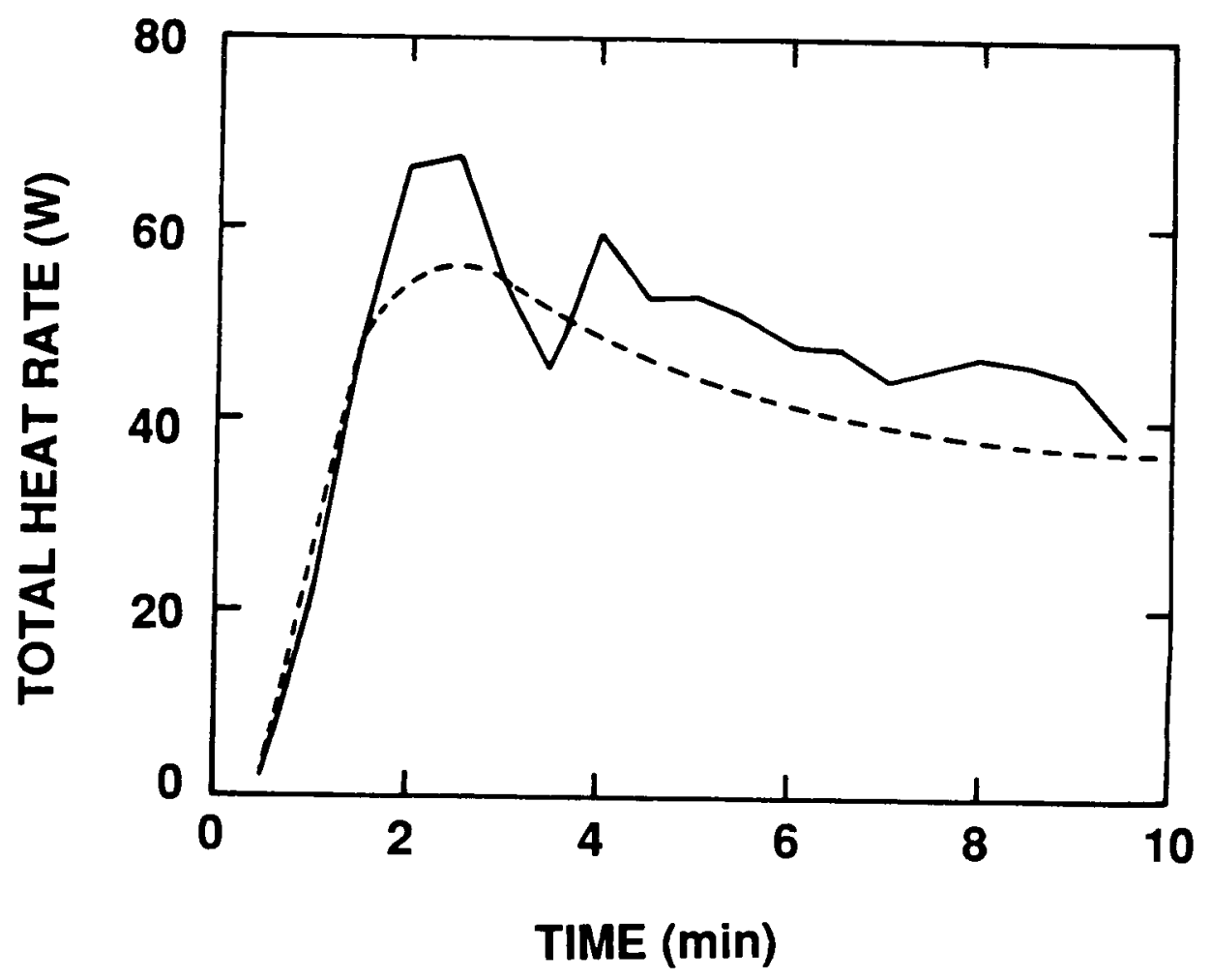

Figure 7. Prediction of total heat rates from the present model (solid line) and the calculated results based on the thermoneutral potential of $3.72 \mathrm{~V}$ (dashed line) for the short circuit test. 


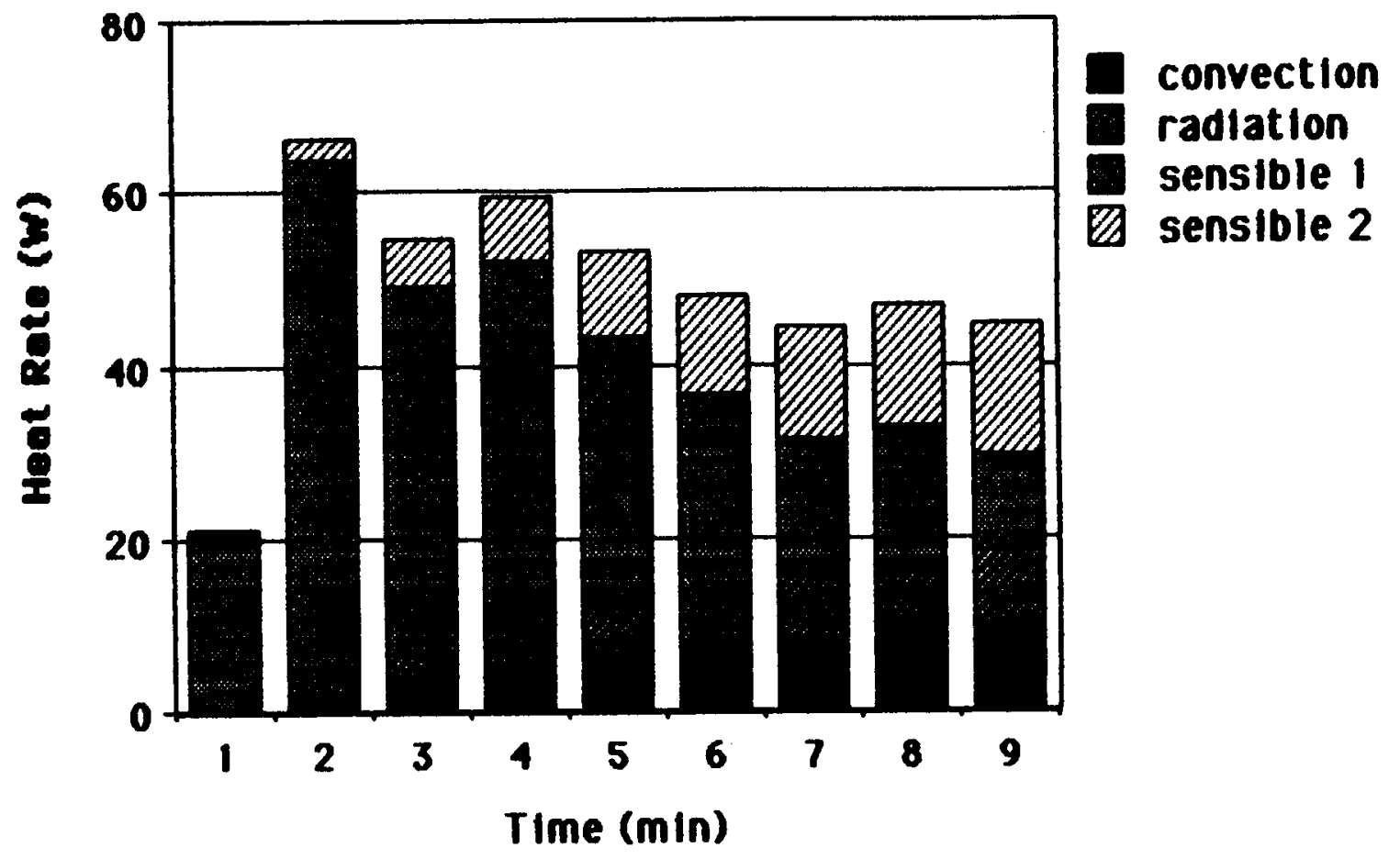

Figure 8. Contributions of convection, radiation, sensible energy (1) and sensible energy correction due to conduction (2) for the short circuit test. 


\title{
Computer Simulation of Thermal Modeling of Primary Lithium Cells
}

\author{
Y. Cho, H. Frank and G. Halpert \\ Drexel University and Jet Propulsion Laboratory
}

November 18, 1986

Goddard Space Flight Center Battery Workshop 


\section{OBJECTIVES}

The goal was to better understand the safety problem of primary $\mathrm{Li}-\mathrm{SOCl}_{2}$ and $\mathrm{Li}-\mathrm{SO}_{2}$ cells by conducting the thermal modeling work.

Specifically, we wanted

i) to predict the total amount of heat generation rate during high discharge rate conditions, and

ii) to understand the mechanism of heat dissipation from the cell 


\section{OBJECTIVES-CONTINUED}

- The time required to reach unsafe conditions for a given cell and given test conditions should be calculated.

- The net difference between the predicted total heat rate from the model $q_{t}$ and the heat calculated from $I\left(O C V-E_{1}\right)$ is due to lithium corrosion and/or other chemical reactions. 
Total Heat Dissipation consists of

- heat convection from cell wall to the surroundings

- heat radiation from cell wall to the surroundings

- energy stored within the cell (sensible energy)

- sensible energy correction due to heat conduction 


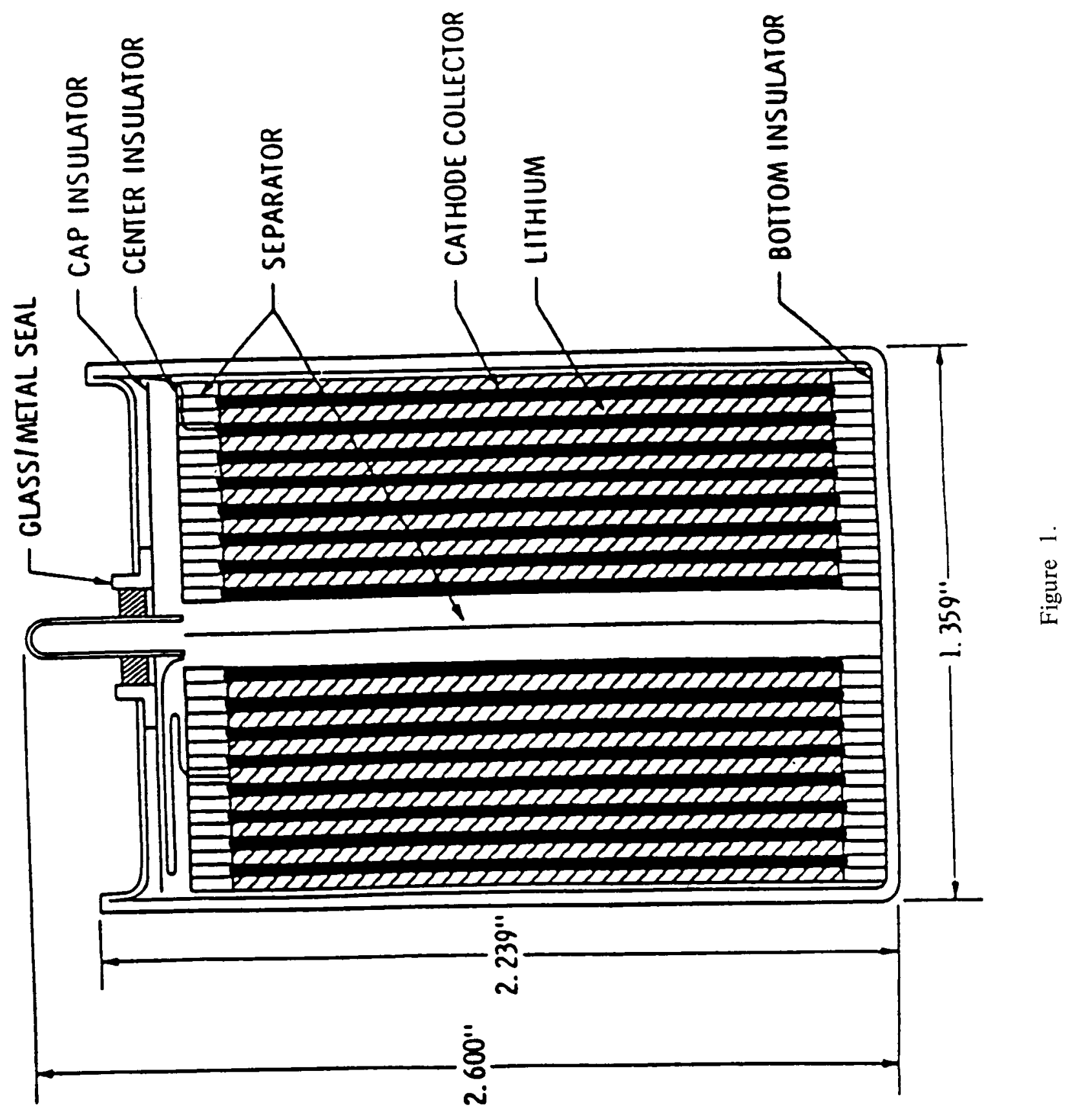


The total heat generation rate is the sum of all four.

$$
q_{\text {total }}=q_{c v}+q_{r}+q_{s 1}+q_{s 2}
$$

The heat balance equation becomes

$$
\begin{aligned}
q_{\text {total }}= & h\left(T_{w}, r\right) A\left(T_{w}-T_{a}\right)+F_{1-2} A \sigma \in\left(T_{w}{ }^{4}-T_{a}{ }^{4}\right) \\
& c_{p} M \frac{d T_{w}}{d t}+q_{s 2}
\end{aligned}
$$

where $T_{w}$ is a function of time. 


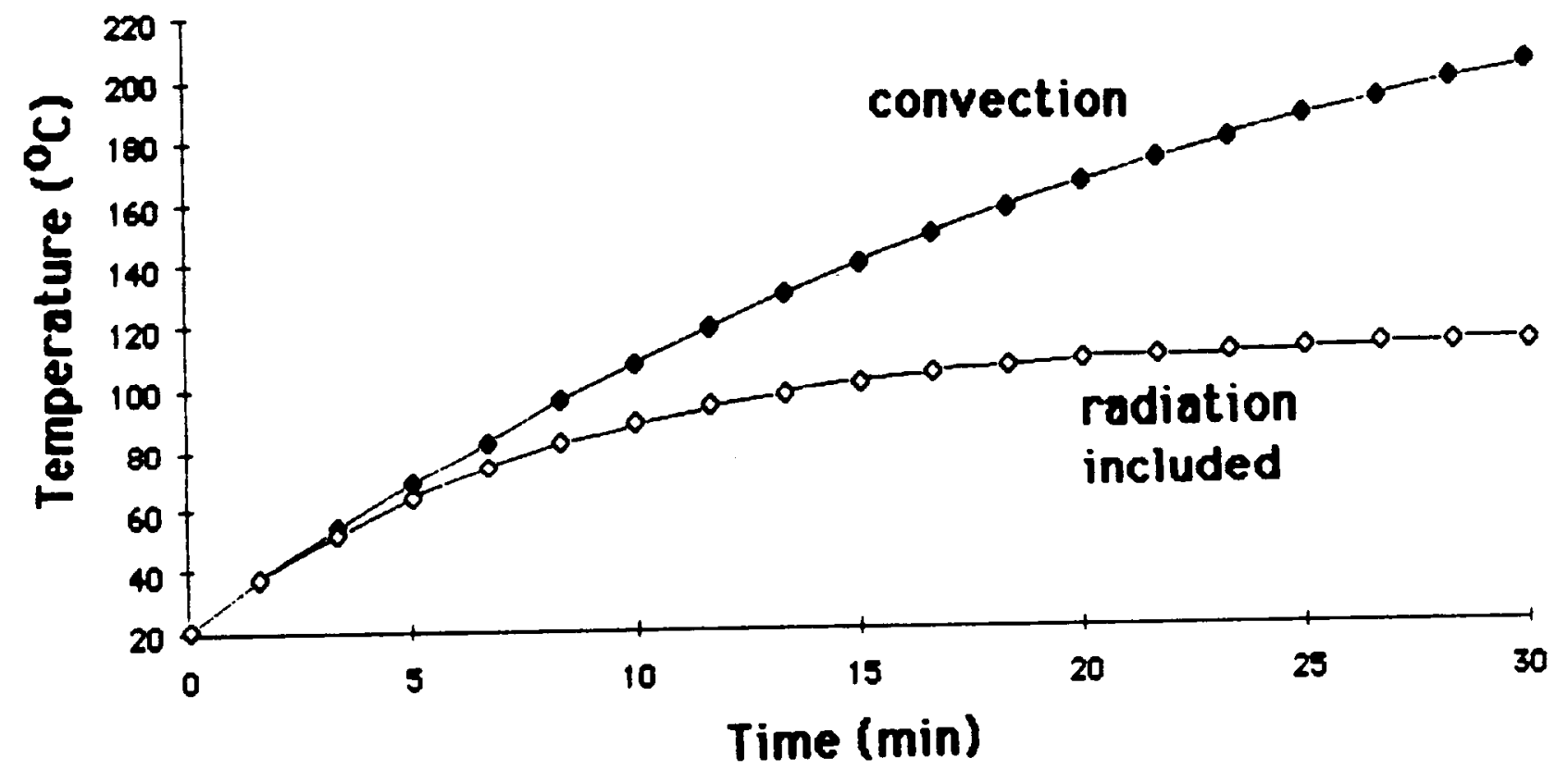

Figure 2. 
THE PRESENT COMPUTER CODE CONSISTED OF TWO PARTS.

Program A i to predict total heat generation rate from the cell wall temperature as a function of time

Program : to predict transient cell temperature from the heat generation rate data

In both cases,

i) internal temperature distributions were automatically produced, and

ii) contributions of heat convection, radiation, internal energy stored within the cell, and heat conduction were automatically identified. 


\section{USER-FRIENDLY CODE:}

Any cylindrical cell can be simulated.

In particular.

i) Detail information on the geometry and cell component materials for $\mathrm{Li}-\mathrm{SOCl}_{2}$ (D-size cell) and $\mathrm{Li}-\mathrm{SO}_{2}$ (Navy's sonobuoy cell) was built-in.

ii) Internal thermal resistances were automatically calculated based on these information to produce internal temperature distributions.

iii) Electrolyte consumption schedules could be given such that a dry or flooded cell could be simulated. 


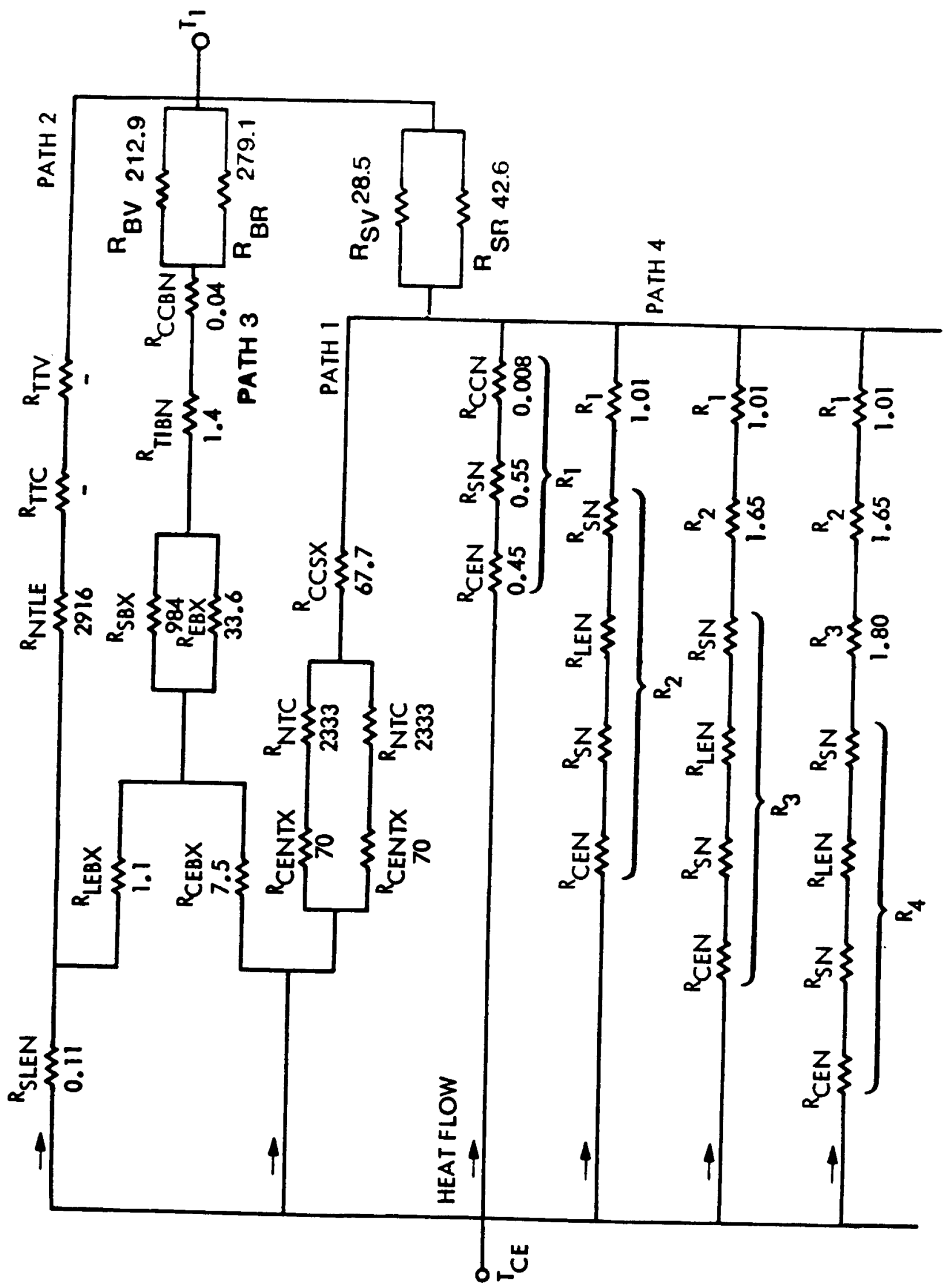



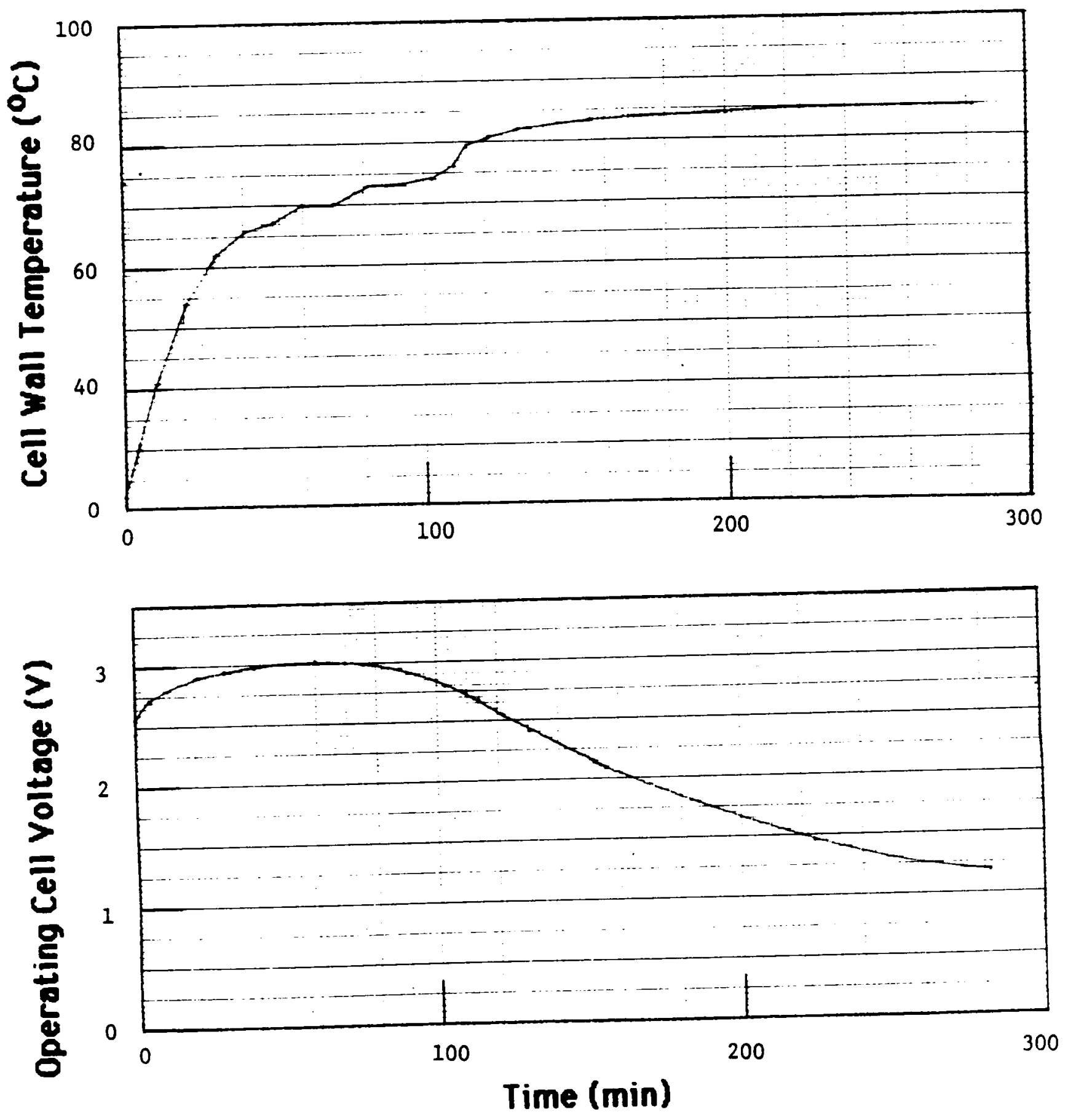

Figure 4. Discharge test under a constant load. 

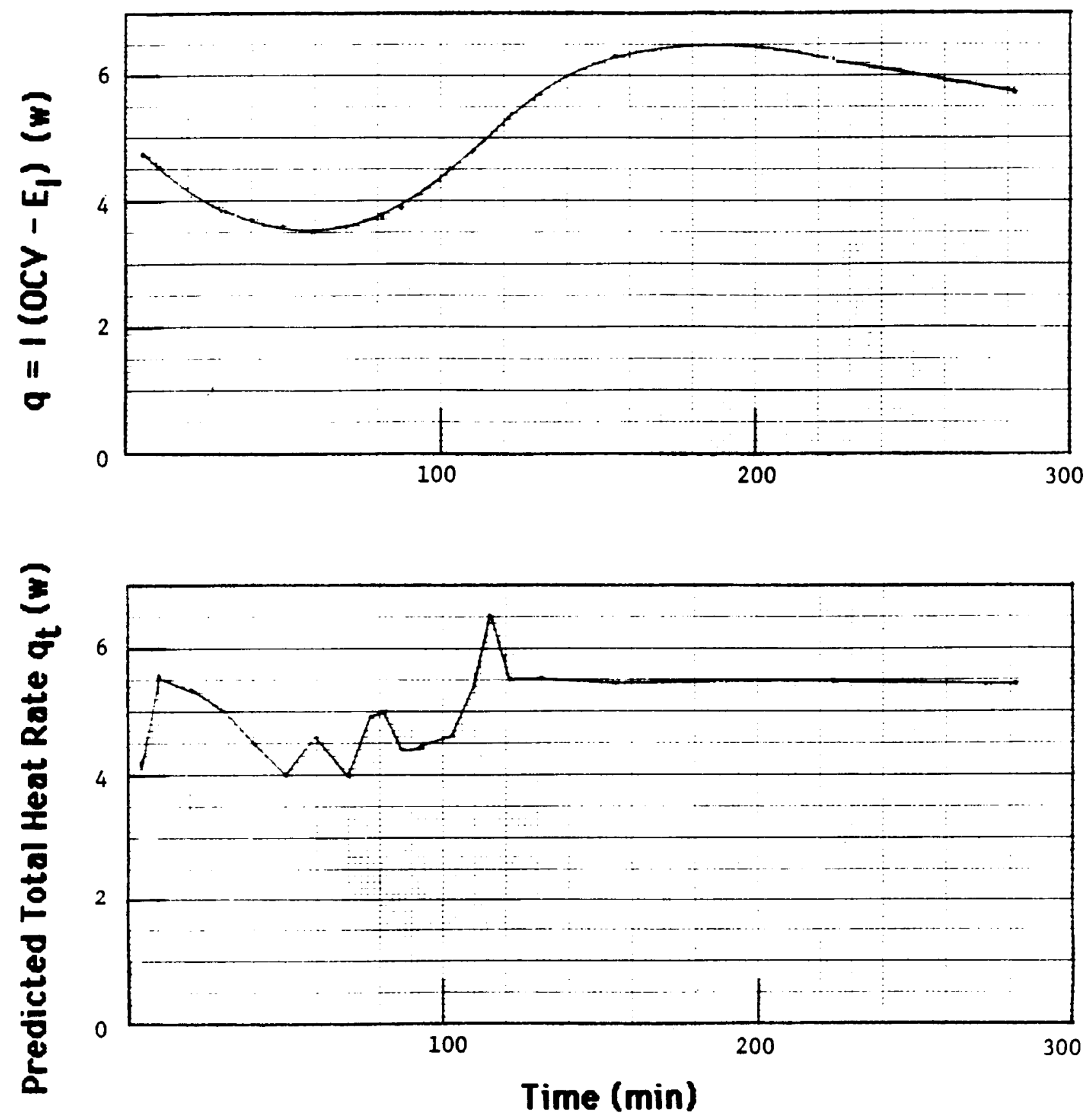

Figure 5. Discharge test under a constant load. 


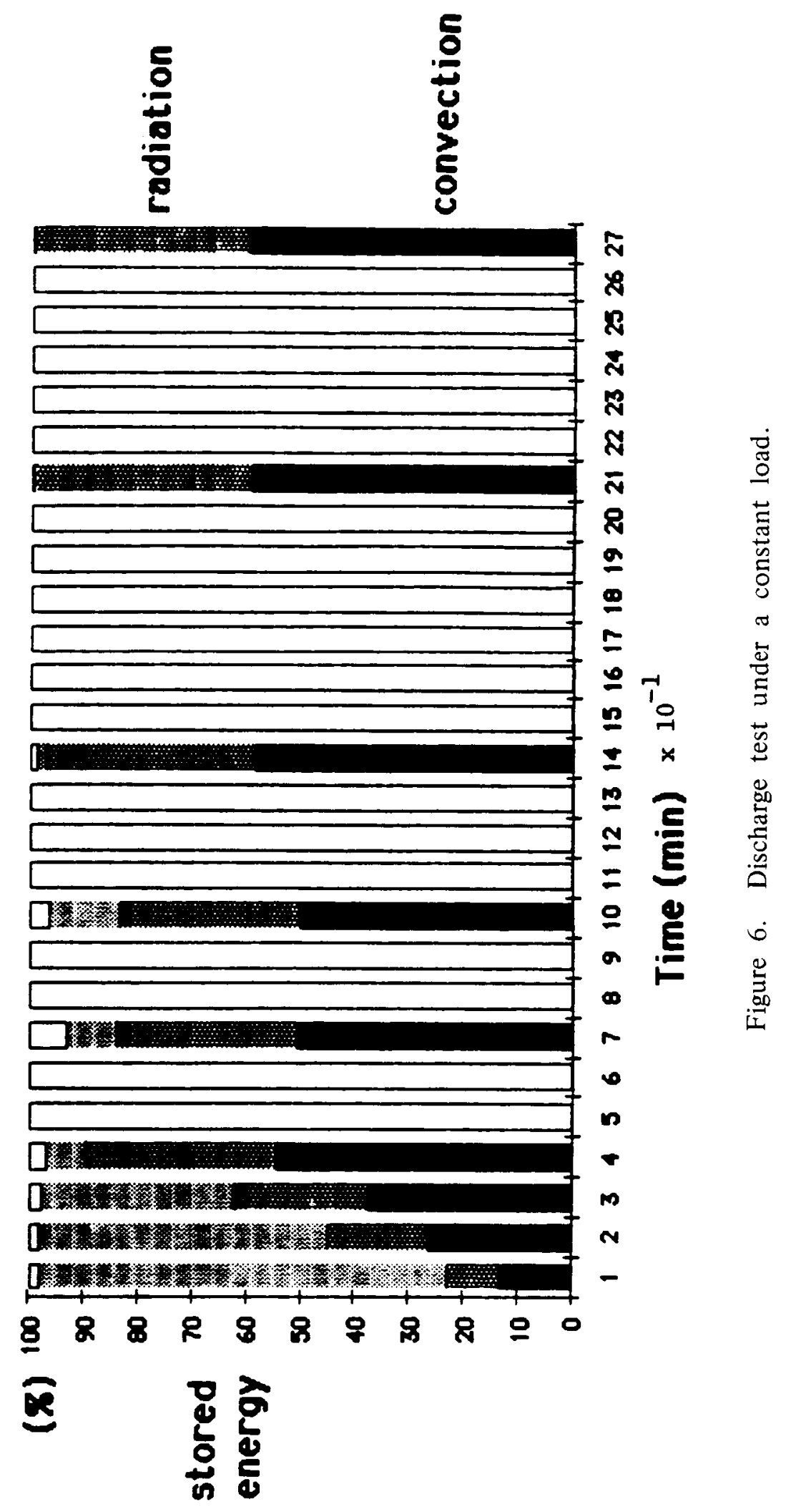




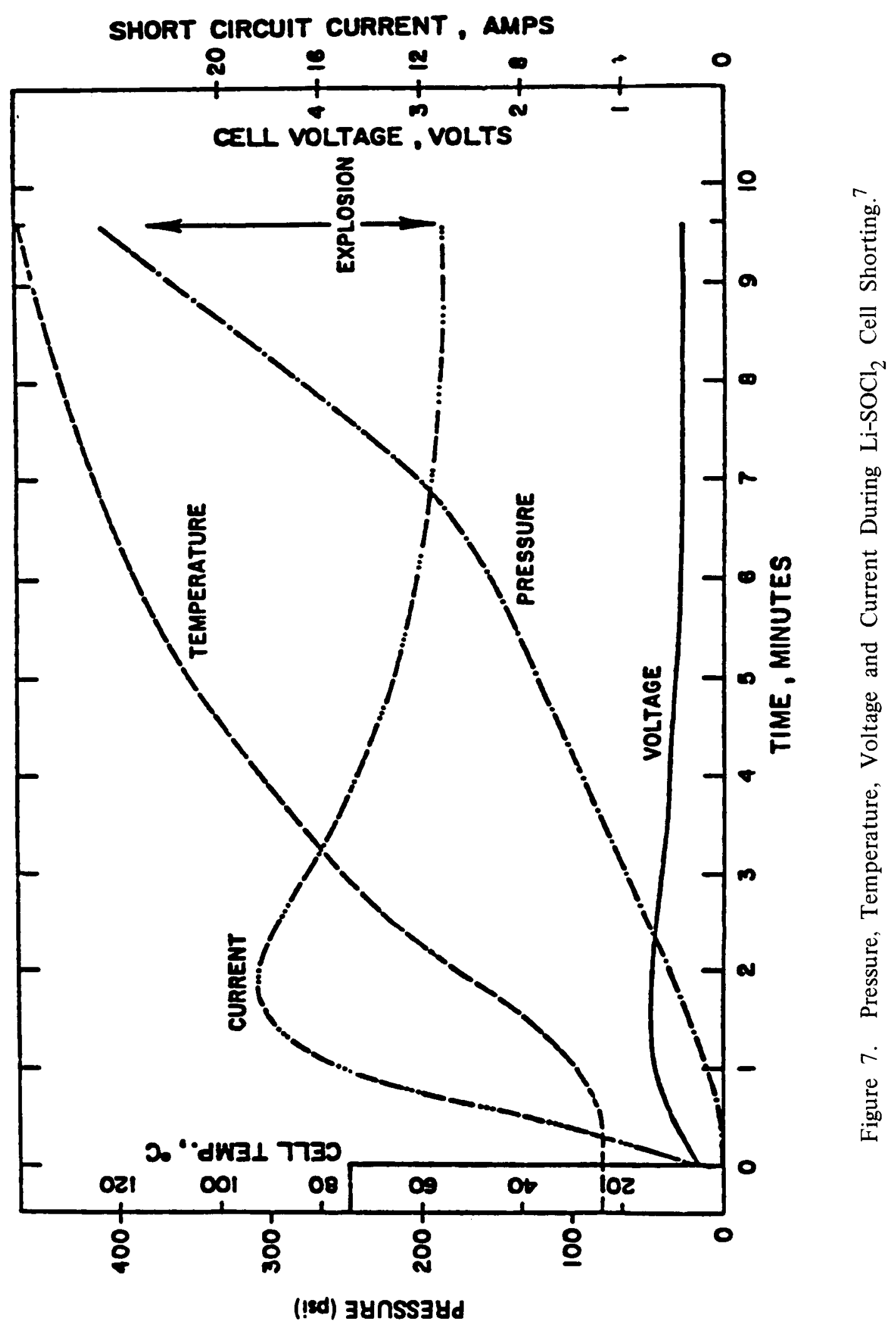




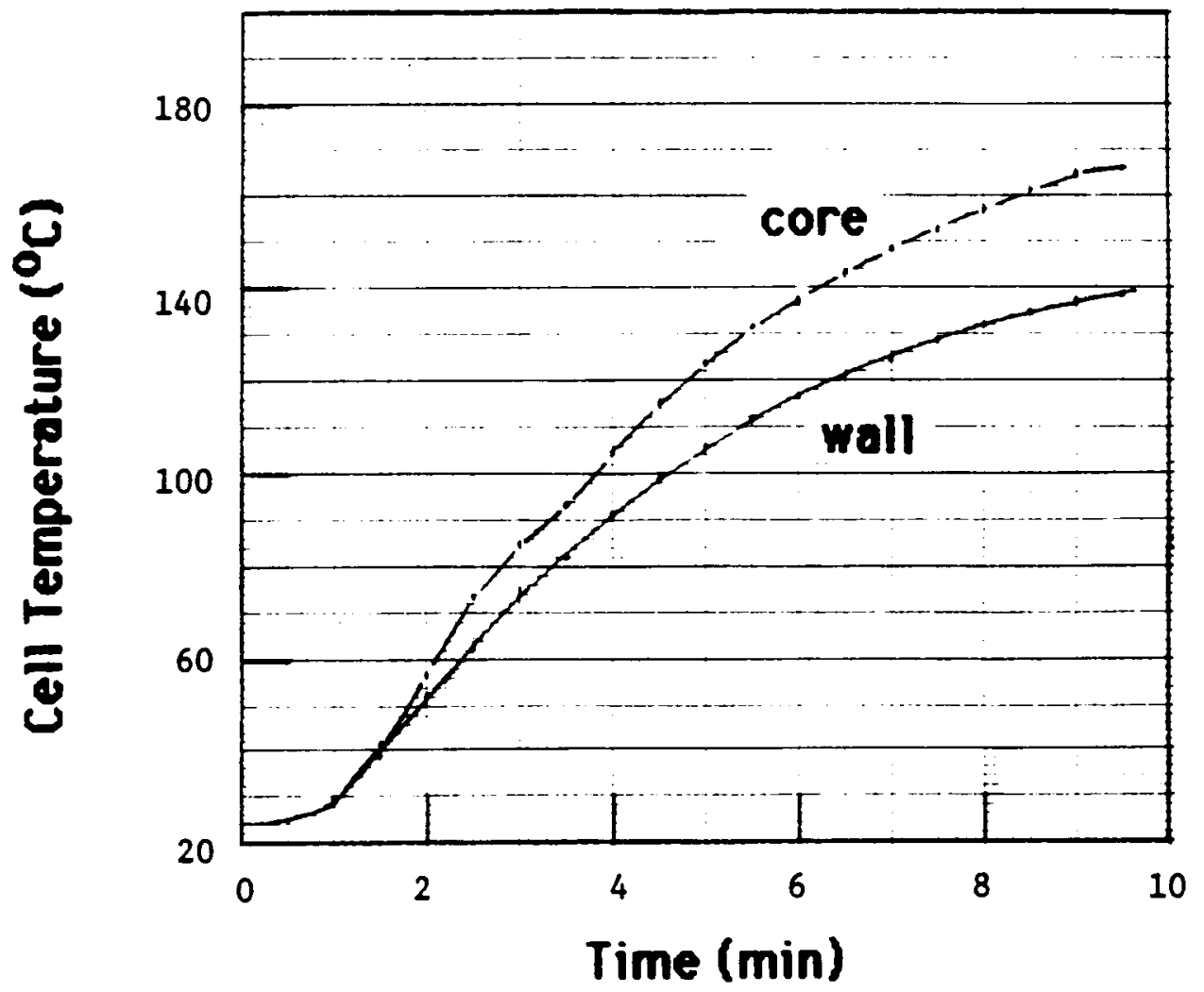

Figure 8. High discharge rate during external short circuit. 

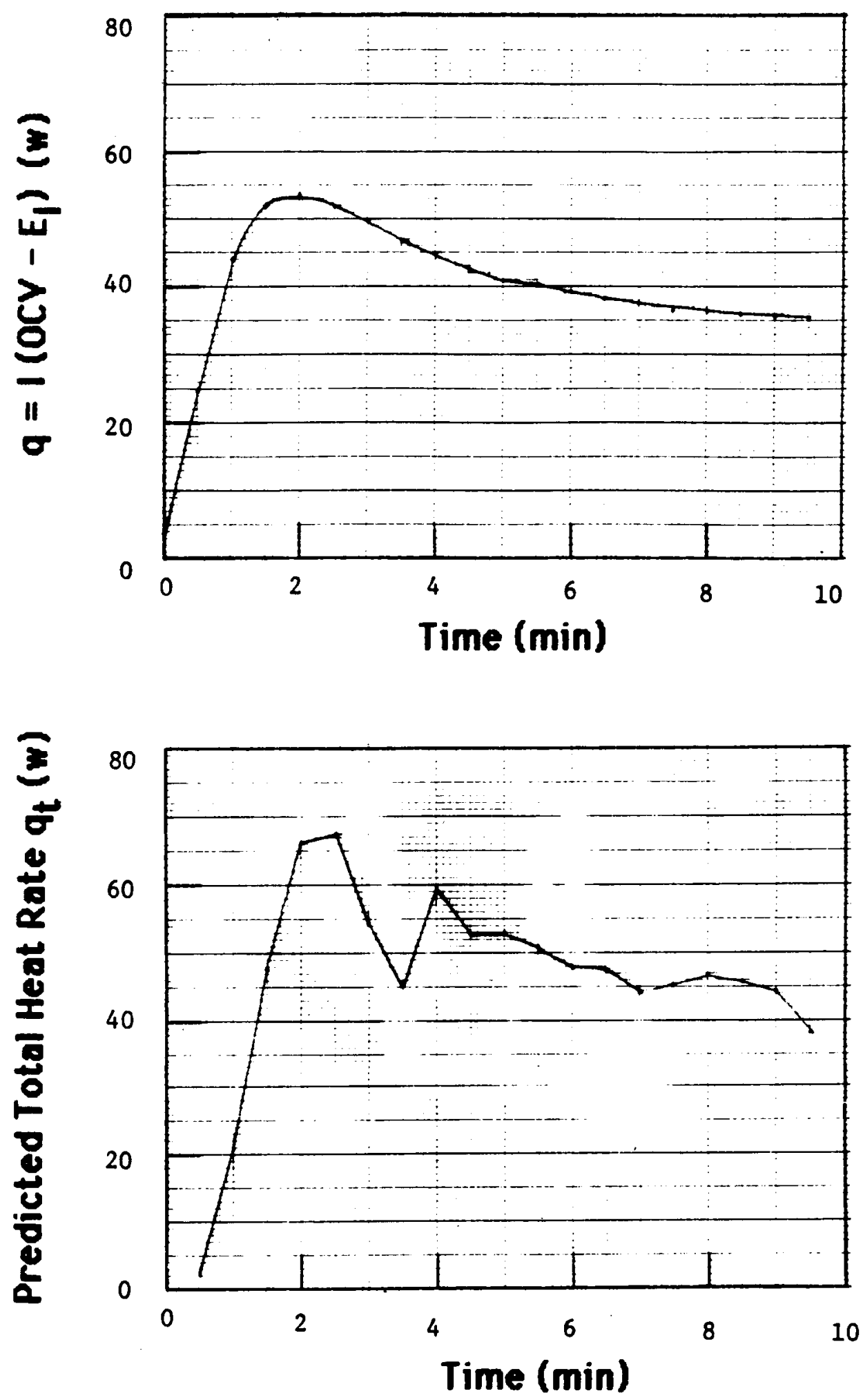

Figure 9. High discharge rate during external short circuit. 


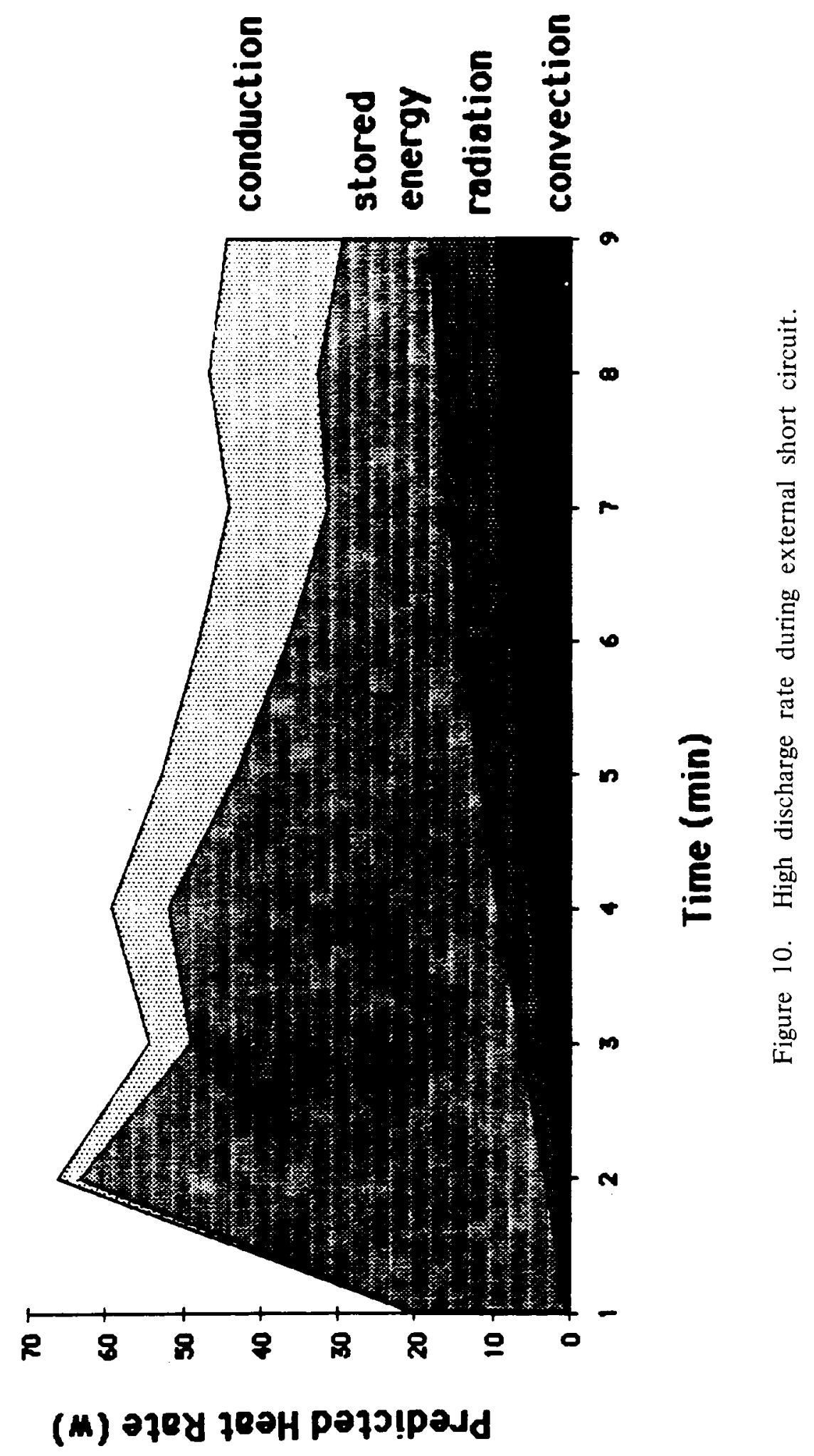



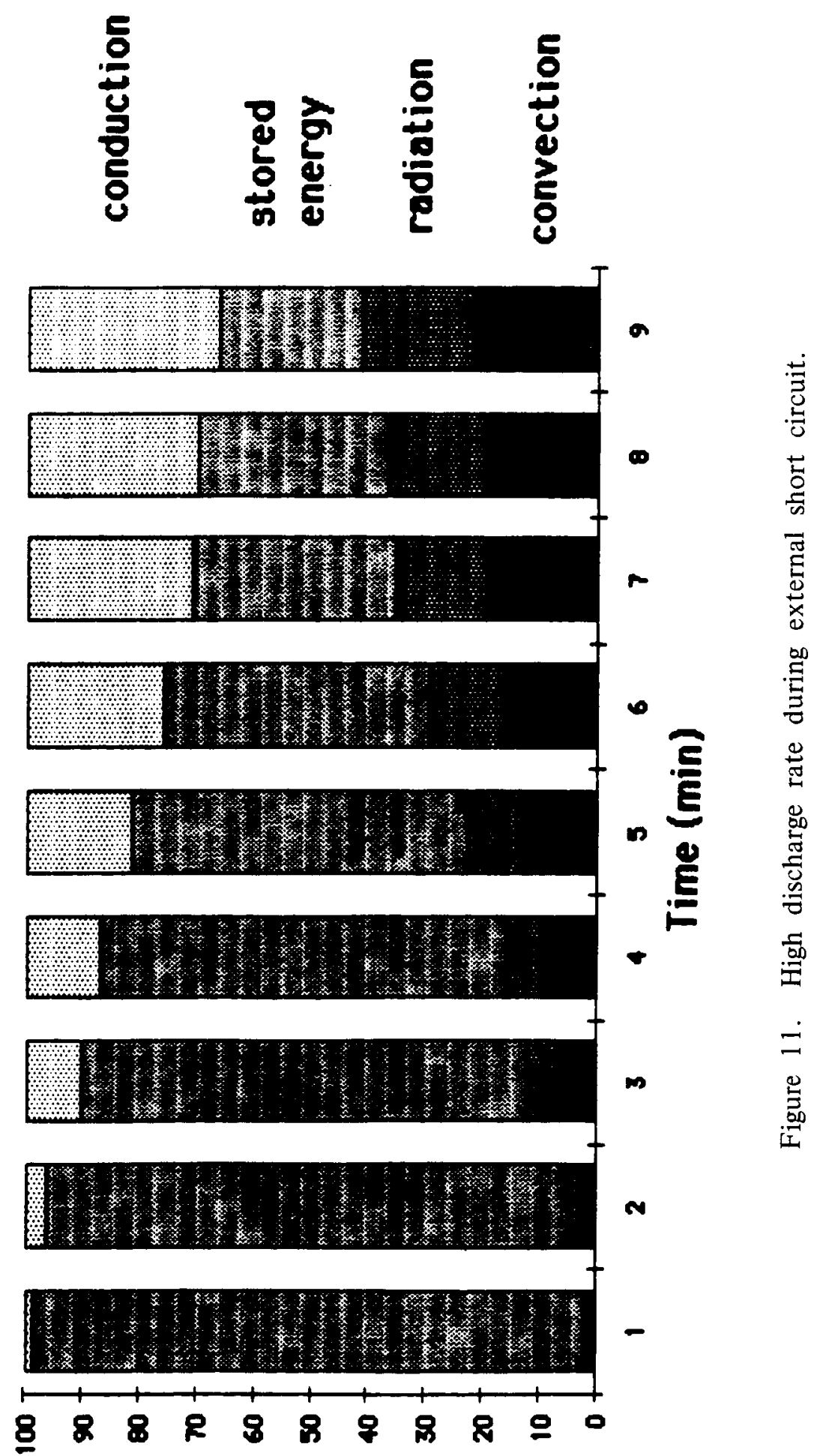

$\bar{\Phi}$ 


\section{CONCLUSIONS}

o The total heat generation rate was calculated from a comprehensive thermal modeling work, including convection and radiation heat dissipation, sensible heat, heat conduction via internal thermal resistance network.

- Under normal discharge rate conditions, convection and radiation are dominant heat dissipation modes.

o However, approaching the explosion or for extremely high discharge rate cases such as external short circuits, convection and radiation dissipate less than $40 x$ of the total heat produced.

o The present code is applicable for other primary cylindrical cells with minor modifications.

o The present methodology is valid for charging tests as well as rechargeable battery analyses. 